\title{
Ten-year follow-up of a case series of primary epithelial neoplasms of the lacrimal gland: clinical features, surgical treatment and histopathological findings
}

\author{
Dez anos de acompanhamento de uma série de casos de neoplasias epiteliais \\ primárias da glândula lacrimal: características clínicas, \\ tratamento cirúrgico e achados histopatológicos
}

\author{
Rodrigo RibeiroSantos ${ }^{1}$ \\ Renato Wendell Ferreira Damasceno ${ }^{2}$ \\ Fernanda Silva Lopes de Pontes $^{3}$ \\ Sylvia Regina T.Cursino ${ }^{4}$ \\ Maria Cristina Nishiwaki-Dantas ${ }^{5}$ \\ José Vital Filho ${ }^{6}$ \\ Paulo Elias Correa Dantas ${ }^{\tau}$
}

\footnotetext{
Study carried out at Department of Ophthalmology, Santa Casa de São Paulo - São Paulo - Brazil.

Fellow, Corneal and External Disease Service, Department of Ophthalmology, Santa Casa de Misericórdia São Paulo - São Paulo (SP) - Brazil.

${ }^{2}$ Postgraduate Student (Doctoral level), Department of Ophthalmology, Universidade Federal de São Paulo UNIFESP - São Paulo (SP) - Brazil.

Ophthalmic Pathology Service, Department of Pathology - Santa Casa de Misericórdia São Paulo - São Paulo (SP) - Brazil.

${ }^{4}$ Professor of Ophthalmology, Oculoplastics Service Department of Ophthalmology - Santa Casa de Misericórdia São Paulo - São Paulo (SP) - Brazil.

${ }^{5}$ Chairwoman, Department of Ophthalmology - Santa Casa de Misericórdia São Paulo - São Paulo (SP) - Brazil.

${ }^{6}$ Director, Oculoplastics Service, Department of Ophthalmology - Santa Casa de Misericórdia São Paulo - São Paulo (SP) - Brazil.

${ }^{7}$ Professor of Ophthalmology, Corneal and External Disease Service, Department of Ophthalmology - Santa Casa de Misericórdia São Paulo - São Paulo (SP) - Brazil.

Correspondence address: Renato Wendell F. Damasceno. Rua Jaguaribe, 102/113 - São Paulo (SP) CEP 01224-000

E-mail: renatowendell@hotmail.com

Recebido para publicação em 05.02.2009

Última versão recebida em 27.10.2009

Aprovação em 14.12.2009
}

\begin{tabular}{l} 
ABSTRACT \\
\hline Purpose: To describe and analyze the features of a cases series of \\
patients with primary epithelial neoplasms of the lacrimal gland, its \\
surgical treatment, and histopathological findings. Methods: Retros- \\
pective evaluation of files from patients with primary epithelial neo- \\
plasms of the lacrimal gland in the period from 1997 to 2007 . All patients \\
with primary epithelial tumors of the lacrimal gland were included in this \\
study. Data on gender, age, clinical features, surgical treatment, histopa- \\
thological findings and follow-up were collected. The slides with his- \\
tological sections of the tumors were reviewed by the same pathologist. \\
Results: During the study period, there were 12 patients, 5 (41.7\%) with \\
benign tumors, all pleomorphic adenomas (benign mixed tumor) and \\
7 (58.3\%) with malignant neoplasms, thus distributed: four cases of \\
adenoid cystic carcinoma, two of mucoepidermoid carcinoma and one \\
carcinoma expleomorphic adenoma. Globally, patients mean age was \\
54.1 years-old (ranging from 14 to 70 years-old), with mean age of 52.4 \\
years-old (ranging from 14 to 65 years-old) for benign neoplasms, and \\
55.3 years-old for malignant neoplasms (ranging from 26 to 70 years-old). \\
Clinical follow-up information, ranging from 2 to 10 years-old, was \\
available for all patients. Three patients developed distant metastasis \\
and died of disease. Conclusions: The most frequent primary epithelial \\
neoplasms of the lacrimal gland were pleomorphic adenoma and adenoid \\
cystic carcinoma during the study period. Malignant tumors were more \\
frequent than benign tumors. The histopathological diagnosis and the \\
disease initial stage can play a significant role in patient's survival.
\end{tabular}

Keywords: Lacrimal apparatus; Orbital neoplasm; Adenoma; Eye neoplasms; Lacrimal apparatus diseases/surgery; Carcinoma, adenoid cystic; Carcinoma, mucoepidermoid; Follow-up studies

\section{INTRODUCTION}

Tumors of the lacrimal gland are uncommon in the clinical practice. $\mathrm{Ne}$ vertheless, they present high morbidity and mortality ${ }^{(1)}$. They constitute approximately $7-9 \%$ of orbital tumors ${ }^{(2-3)}$ and are generally divided into four categories: inflammatory lesions, lymphomas, metastatic cancer, and epithelial tumors ${ }^{(4)}$. 
Inflammatory and lymphoid lesions are more frequent than epithelial neoplasias ${ }^{(5)}$. Metastatic carcinoma to the lacrimal gland is uncommon but can be observed, mainly associated with breast and lung carcinoma ${ }^{(6)}$. Epithelial neoplasms represent approximately $30 \%$ of the lesions of the lacrimal gland ${ }^{(3-4)}$. The most common epithelial tumors are, in order, pleomorphic adenoma (benign mixed tumor), adenoid cystic carcinoma, and adenocarcinoma ${ }^{(4,7-12)}$. Other rare variants of carcinoma are also seen, such as mucoepidermoid carcinoma and carcinoma ex pleomorphic adenoma (malignant mixed tumor) ${ }^{(4)}$. Some of the primary malignant epithelial tumors may come from a preexisting pleomorphic adenoma (benign mixed tumor) through a malignant transformation, but most arises de novo ${ }^{(4,7)}$. The malignant components of the carcinoma ex pleomorphic adenoma (malignant mixed tumor) can be an undifferentiated carcinoma, a poorly differentiated adenocarcinoma, an adenoid cystic carcinoma, or an epithelial-myoepithelial carcinoma ${ }^{(8,13)}$.

The clinical presentation of the benign neoplasm of the lacrimal gland is characterized by painless palpable mass, slow growth and displacement of the globe off axis ${ }^{(7,14-17)}$. Clinical suspicion for a malignancy is raised by a recent rapid onset of symptoms, pain, and radiographic evidence of bone destruc$\operatorname{tion}^{(8,14-16)}$.

Histologically, the lacrimal gland is composed of acini with an inner layer of cuboidal to columnar zymogen-bearing cells and an outer layer of myoepithelial cells. Involutional changes include fibrosis, atrophy, ductal dilation, ductal proliferation, lymphocytic infiltration, and fatty infiltration ${ }^{(18)}$.

The purpose of this study is to describe and analyze the clinical features, surgical treatment, histopathological findings and follow-up of patients with primary epithelial neoplasms of the lacrimal gland in a tertiary referral center from 1997 to 2007.

\section{METHODS}

A retrospective and observational study was performed to evaluate cases of epithelial neoplasias of the lacrimal gland treated between 1997 and 2007, in a tertiary referral center in São Paulo, Brasil. Patients with extrinsic lesions encroaching the lacrimal gland and metastatic tumors to the lacrimal gland were excluded. Data about gender, age, clinical features, surgical treatment, histopathological findings and follow-up were collected from hospital files. Follow-up information ranging from 2 to 10 years was available for all patients. The tumors histological sections were all reviewed by the same pathologist, masked to the previous diagnosis.

This study was conducted in compliance with the tenets of the local ethical committee and the tenets of the Declaration of Helsinki for experiments involving human tissue.

\section{RESULTS}

There were seven female (three pleomorphic adenomas, two adenoid cystic carcinomas, one mucoepidermoid carci- noma and one carcinoma ex pleomorphic adenoma), and five male (two pleomorphic adenomas, two adenoid cystic carcinoma and one mucoepidermoid carcinoma) cases (table 1). All patients were adults, except for a 14 year-old girl. The patients mean age was 54.1 years-old (range, 14 to 70 yearsold); 52.4 years-old (range, 14 to 65 years-old) for benign neoplasms and 55.3 years-old (range, 26 to 70 years-old) for malignant neoplasms. The right lacrimal glands were affected in seven cases, and the left in five cases. No bilateral tumors were noted (table 1 ).

Five patients (41.7\%) had benign tumors. All benign neoplasias were pleomorphic adenomas (benign mixed tumors). The mean age of the patients with pleomorphic adenoma was 52.4 years-old (range, 14 to 65 years-old). All patients presented a painless palpable mass of slow growth, and an inferomedial displacement of the globe (Table 2). The patients were treated with lateral orbitotomy and en bloc resection of the lesion with the intact capsule. Macroscopically, all tumors were circumscribed and encapsulated (Figure 1A). Microscopically, all neoplasms were composed mainly of epithelial cells and ductal structures, with myxoid and chondroid background. Of these, three cases were of cellular pattern (Figure 2A), and two were of myoepithelial pattern (Figure 2B). The mean follow-up period was 6.4 years (range, 4 to 8 years). There was no recurrence of the disease during this period.

Regarding the malignant neoplasias (seven patients, 58.3\%), there were four cases of adenoid cystic carcinoma. The mean age of the patients with adenoid cystic carcinoma was 51 years-old (range, 26 to 65 years-old). Two patients presented a painful palpable mass of rapid growth, proptosis and inferomedial displacement of the globe, and two presented reduced visual acuity, choroidal folds, restricted ocular motility and swelling. Two patients were treated with lateral orbitotomy with resection of the tumor and postoperative radiation, and two were treated with orbital exenteration and postoperative radiation. In these patients, the orbital exenteration and the postoperative radiation were chosen because the preoperative axial and coronal computed tomography showed diffuse orbital involvement, including extraocular muscles and optic nerve. Macroscopically, the tumor was rounded and irregular (Figure 1B). Histologically, two cases were of cribriform pattern (Figure 2C), and two were of solid growth pattern (Figure 2D). One case with cribriform pattern and two cases with solid growth pattern showed necrosis and perineural invasion. The other case with cribriform pattern presented no necrosis and perineural invasion. According to the UICC/TNM Classification, the two cases of cribriform pattern were classified as T2NOM0, and the two cases of solid growth pattern were classified as T4N0M0. The mean follow-up period was 6.5 years (range, 4 to 10 years). No tumoral recurrence was observed in two patients (adenoid cystic carcinoma with cribriform pattern). The patients with solid growth pattern and T4N0M0 developed metastasis to the brain and died of the disease. 


\begin{tabular}{|c|c|c|c|c|c|c|c|}
\hline 1 & $\mathrm{~F}$ & 65 & Left & - & PA & Lateral orbitotomy and complete resection & 4 years/no evidence of disease \\
\hline 3 & M & 61 & Right & - & $\mathrm{PA}$ & Lateral orbitotomy and complete resection & 6 years/no evidence of disease \\
\hline 4 & $\mathrm{~F}$ & 59 & Left & - & PA & Lateral orbitotomy and complete resection & 8 years/no evidence of disease \\
\hline 5 & $\mathrm{~F}$ & 14 & Right & - & PA & Lateral orbitotomy and complete resection & 7 years/no evidence of disease \\
\hline 7 & M & 63 & Left & T4N0M0 & $\mathrm{ACC}$ & $\begin{array}{l}\text { Orbital exenteration and } \\
\text { postoperative radiation }\end{array}$ & 4 years/metastasis/died of disease \\
\hline 8 & $\mathrm{~F}$ & 50 & Right & T2NOMO & $\mathrm{ACC}$ & Lateral orbitotomy and postoperative radiation & 8 years/no evidence of disease \\
\hline 9 & $\mathrm{~F}$ & 26 & Right & T2NOMO & $\mathrm{ACC}$ & Lateral orbitotomy and postoperative radiation & 10 years/no evidence of disease \\
\hline 10 & M & 70 & Right & T4N1M0 & MC & $\begin{array}{l}\text { Orbital exenteration, maxillectomy, } \\
\text { ethmoidectomy and postoperative radiation }\end{array}$ & 2 years/died of disease \\
\hline
\end{tabular}

\begin{tabular}{|c|c|}
\hline Tumor & Features \\
\hline Pleomorphic adenoma & $\begin{array}{l}\text { Painless } \\
\text { Slow growth } \\
\text { Round, encapsulated and regular lesion } \\
\text { Bony erosion }\end{array}$ \\
\hline Adenoid cystic carcinoma & $\begin{array}{l}\text { Painful } \\
\text { Rapid growth } \\
\text { Encapsulated or not and irregular lesion } \\
\text { Bony erosion } \\
\text { Infiltration into the adjacent structures }\end{array}$ \\
\hline Mucoepidermoid carcinoma & $\begin{array}{l}\text { Painful } \\
\text { Rapid growth } \\
\text { Encapsulated or not, heterogeneous with } \\
\text { mucus and irregular lesion } \\
\text { Bony erosion } \\
\text { Infiltration into the adjacent structures } \\
\text { Infiltration into the sinus }\end{array}$ \\
\hline $\begin{array}{l}\text { Carcinoma ex } \\
\text { pleomorphic adenoma }\end{array}$ & $\begin{array}{l}\text { Painful } \\
\text { Rapid growth } \\
\text { Encapsulated, with benign and } \\
\text { malignant areas and irregular lesion } \\
\text { Bony erosion }\end{array}$ \\
\hline
\end{tabular}

The other malignant neoplasms were two cases of mucoepidermoid carcinoma and one case of carcinoma ex pleomorphic adenoma (malignant mixed tumor).

The first patient with mucoepidermoid carcinoma was a 70 year-old man, and the second was a 58 year-old woman. Both patients presented a painful palpable mass, proptosis, displacement of the globe off axis, swelling, reduced visual acuity and choroidal folds. The first patient had infiltration into the maxillary and the ethmoid sinus (Figures 3A, B and C) and was treated with orbital exenteration, maxillectomy, ethmoidectomy, postoperative radiation and postoperative chemotherapy. The second patient was treated with lateral orbitotomy with complete resection of the tumor and postoperative radiation. Macroscopically, the second patient showed a soft and reddish tumor (Figure 1C). Histologically, both cases were low-grade and composed of epidermoid cells with mucus-filled vacuoles embedded in a mucoid background (Figure $2 \mathrm{E}$ ). The mean follow-up was 3.5 years (range, 2 to 5 years). According to the UICC/TNM Classification, the first case was classified as $\mathrm{T} 4 \mathrm{~N} 1 \mathrm{M} 0$, and the second case was classified as T3aN0M0. The first patient developed metastasis to the brain and died of the disease. The second patient presented no evidence of recurrence of the disease five years after the initial surgery.

The patient with carcinoma ex pleomorphic adenoma (malignant mixed tumor) was a 55 year-old woman presenting a painful palpable mass of rapid growth, proptosis and displacement of the globe off axis. She was treated with lateral orbitotomy with complete resection of the tumor and postoperative radiation. Macroscopically, the tumor measured 40x20x17 mm, was partially encapsulated, and had an irregular reddish surface (Figure 1D). It was composed of benign (pleomorphic adenoma) and malignant (adenoid cystic carcinoma) components (Figure 2F). According to the UICC/TNM Classification, the tumor was classified as T3aN0M0. Four years after the surgery, there was no evidence of recurrence or metastasis.

Data about gender, age, laterality, staging, diagnosis, management, follow-up and outcomes were summarized in the table 1. Data about the features of epithelial neoplasms of the lacrimal gland were summarized in table 2. Symptoms and signs were summarized in table 3 . 

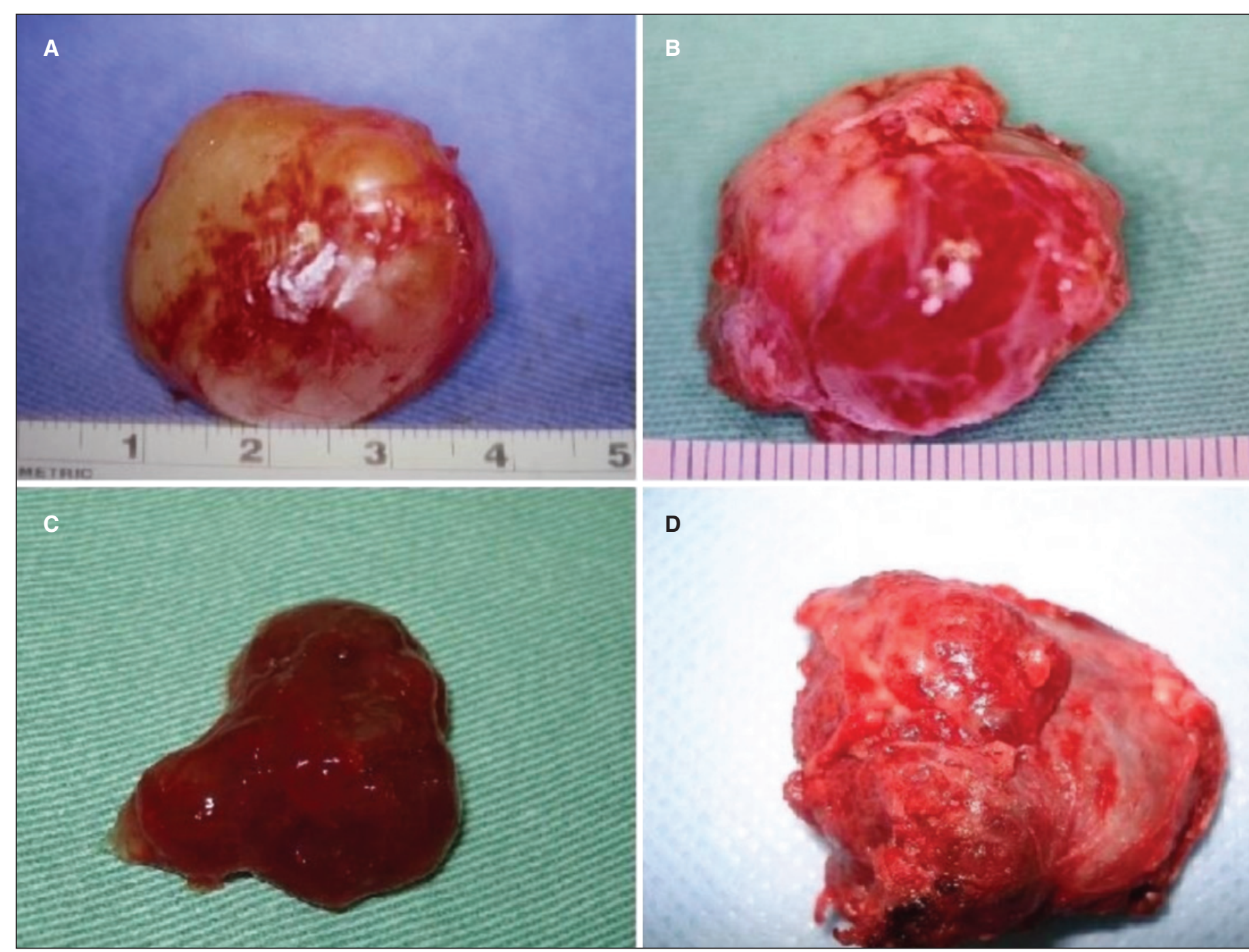

D

Figure 1 - Macroscopically, epithelial neoplasm of the lacrimal gland; A) Pleomorphic adenoma; B) Adenoid cystic carcinoma; C) Mucoepidermoid carcinoma; D) Carcinoma ex pleomorphic adenoma

\section{DISCUSSION}

This case series showed no predilection for gender, agreeing with the literature ${ }^{(7,15-16)}$. However, some authors observed preponderance of males in the malignant neoplasms ${ }^{(14)}$.

Regarding the age, this study observed a higher mean age (54.1 years) than the mean age of the literature for benign and malignant neoplasms ${ }^{(14-16)}$.

Epithelial malignant neoplasms predominated in this review, probably because this institution is a tertiary referral center. The benign epithelial neoplasias are more common than the malignant epithelial neoplasms in the literature ${ }^{(4,12)}$.

This study showed a higher mean age of the patients with pleomorphic adenoma (52.4 years) than the patients mean age in the literature (41 years) $)^{(9)}$. Only one pleomorphic adenoma occurred in a child (14 years-old). Benign and malignant neoplasias of the lacrimal gland are rare in children and adolescents ${ }^{(12,19)}$. Others cases in children and adolescents were reported in the literature ${ }^{(19-21)}$. In this case series, all patients presented a painless palpable mass with slow growth and inferomedial displacement of the globe, agreeing with the literature $^{(15,22-23)}$. In this series, all cases were treated with en bloc resection of the tumor without prior biopsy. This type of wellcircumscribed and encapsulated tumor must be removed en bloc because incisional biopsy is usually associated with malignant transformation ${ }^{(9,15,20)}$.

This study confirmed the previous findings of other authors that adenoid cystic carcinoma is the most common malignant tumor of the lacrimal gland $\mathrm{d}^{(4,9,11,12,14)}$. In this case series, the mean age was 51.4 years-old (range, 26 to 65 yearsold). It often affects patients in the fourth and fifth decade of life ${ }^{(4,12)}$. Two patients presented a painful palpable mass with rapid growth, proptosis and inferomedial displacement of the globe, and two presented, in addition to the symptoms and signs above, reduced visual acuity, choroidal folds, restricted ocular motility and swelling. According to the lite- 

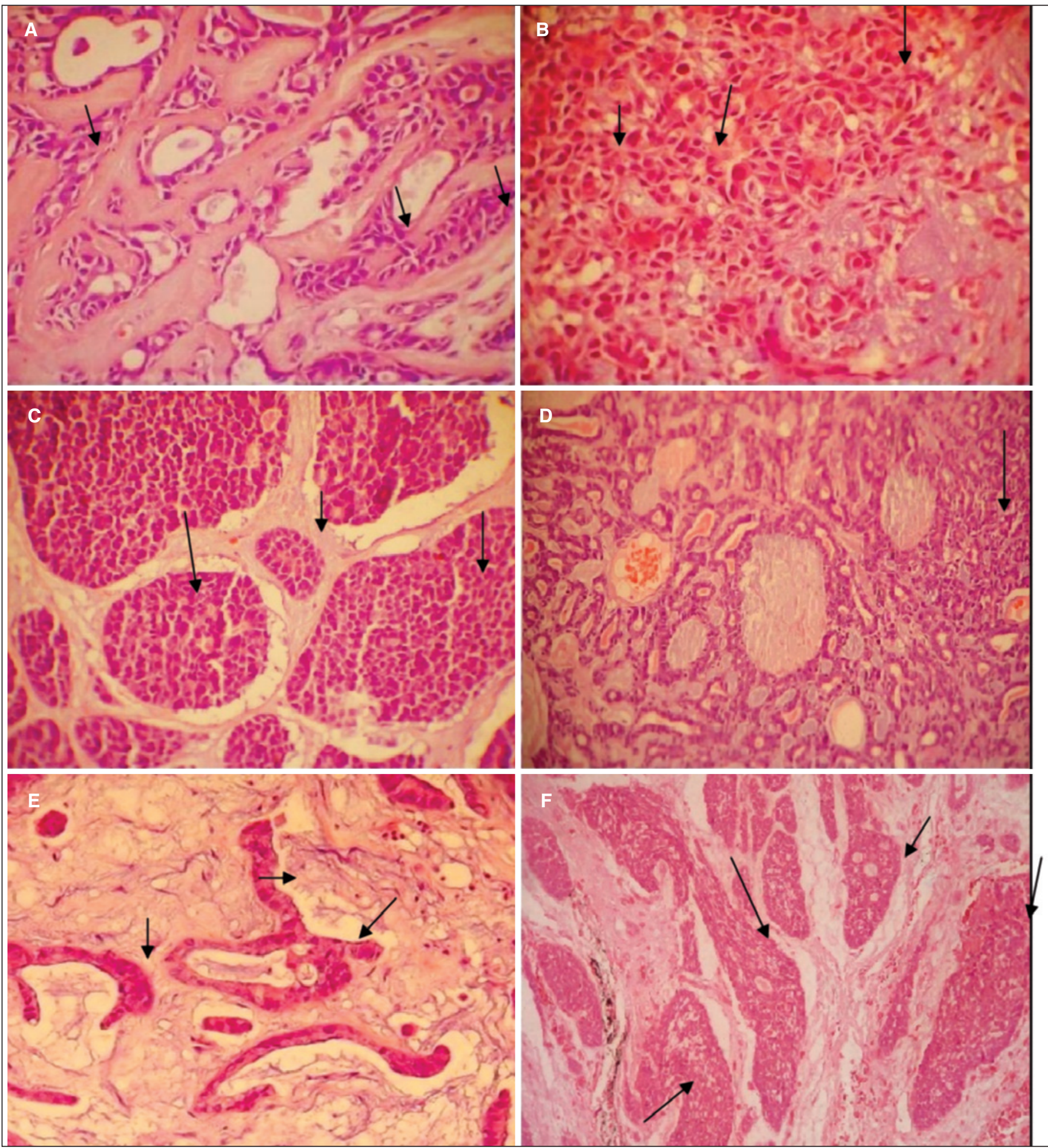

Figure 2 - Microscopically, epithelial neoplasm of the lacrimal gland; A) Pleomorphic adenoma with cellular pattern; B) Pleomorphic adenoma with myoepithelial pattern; C) Adenoid cystic carcinoma with cribriform pattern; D) Adenoid cystic carcinoma with solid growth pattern; E) Low grade mucoepidermoid carcinoma; F) Carcinoma ex pleomorphic adenoma. Hematoxylin and eosin, original magnification x100.

rature, the adenoid cystic carcinoma is characterized clinically by a painful palpable mass with rapid growth, proptosis and inferomedial displacement of the globe ${ }^{(24)}$. Two cases with solid growth pattern presented an aggressive behavior with reduced visual acuity, restricted ocular motility, choroidal folds and swelling. Regarding the treatment, most authors 

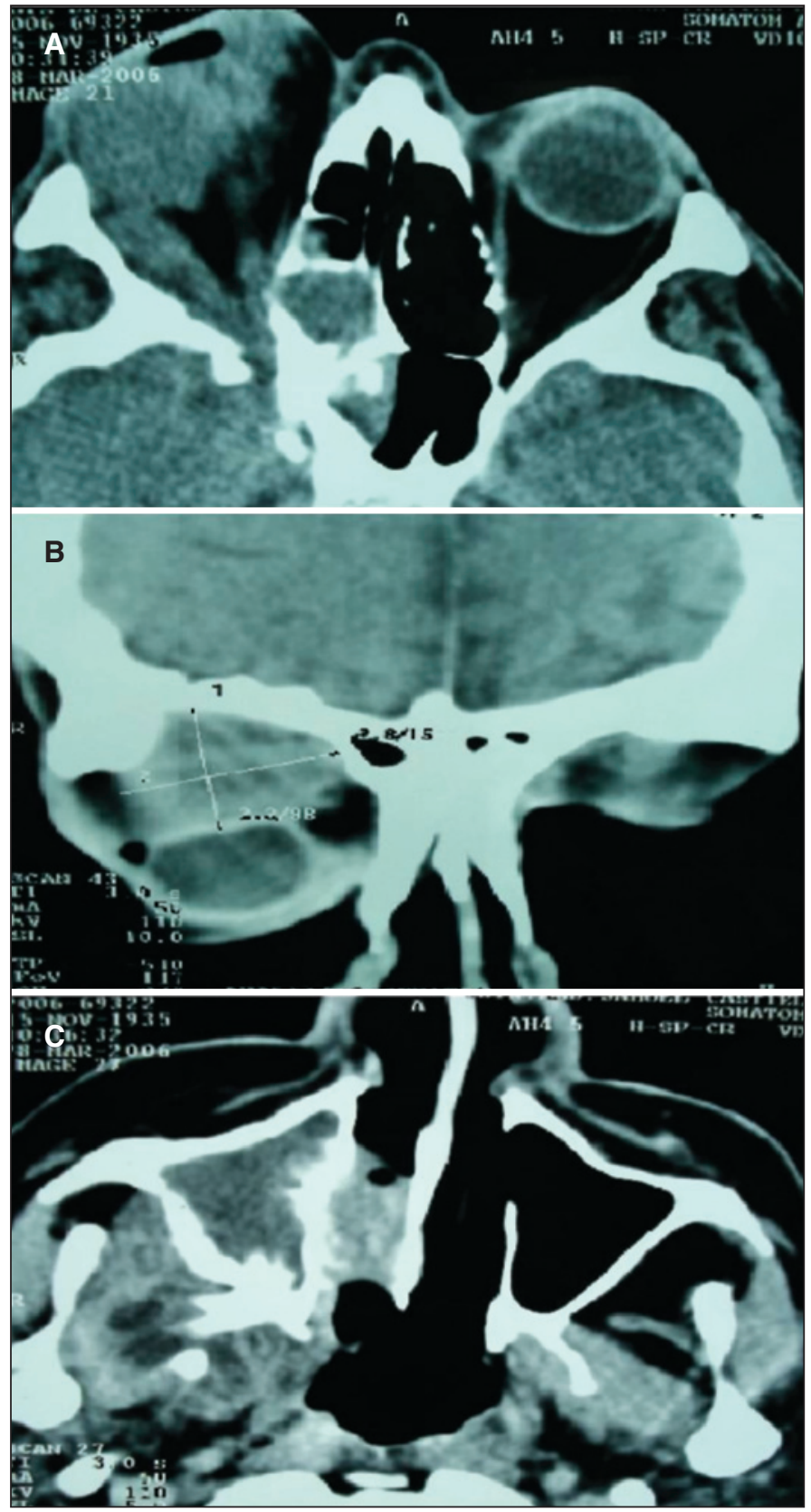

Figure 3 - A) Preoperative axial view computed tomography with enhancement showing the tumor in the right orbit and the infiltration into the ethmoid sinus; B) Preoperative coronal view computed tomography with enhancement showing the tumor in the right orbit; C) Preoperative axial view computed tomography with enhancement showing the infiltration into the maxillary sinus

recommend an aggressive approach with complete resection of the tumor and postoperative radiation ${ }^{(4,14)}$. According to the UICC/TNM Classification, two cases of cribriform pattern were classified as T2N0M0, and two cases of solid growth pattern were classified as T4N0M0. The present case series showed two cases with solid growth pattern and T4N0M0 with distant metastasis four years after the surgery. These findings corroborate with previous conclusions of others in-
Table 3. Clinical findings of patients with epithelial neoplasm of the lacrimal gland. Santa Casa de São Paulo - São Paulo, Brazil, 2009

\begin{tabular}{lcc}
$\begin{array}{l}\text { Symptoms } \\
\text { and signs }\end{array}$ & $\begin{array}{c}\text { Benign epithelial } \\
\text { neoplasm }\end{array}$ & $\begin{array}{c}\text { Malignant epithelial } \\
\text { neoplasm }\end{array}$ \\
Palpable mass & $5 / 5$ & $7 / 7$ \\
Proptosis & $2 / 5$ & $7 / 7$ \\
$\begin{array}{l}\text { Displacement of the } \\
\text { globe off axis }\end{array}$ & $5 / 5$ & $7 / 7$ \\
Blepharoptosis & $2 / 5$ & $7 / 7$ \\
Rapid growth & - & $7 / 7$ \\
Painless & $5 / 5$ & - \\
Slow growth & $5 / 5$ & - \\
Painful & - & $7 / 7$ \\
Reduced visual acuity & - & $4 / 7$ \\
Choroidal folds & - & $4 / 7$ \\
Restricted ocular motility & - & $2 / 7$ \\
Swelling & - & $4 / 7$ \\
\hline
\end{tabular}

vestigators that the histologic pattern and initial staging of disease is of prognostic significance ${ }^{(24-26)}$.

Mucoepidermoid carcinoma is a rare form of malignant tumor of the lacrimal gland ${ }^{(5)}$. In this study, the patients with mucoepidermoid carcinoma were a 70 year-old man and a 58 year-old woman. This neoplasia is more common in younger women, with a mean age of 49 years-old ${ }^{(5)}$. According to the UICC/TNM Classification, the first case was classified as T4N1M0, and the second case was classified as T3aN0M0. The first patient with T4N1M0 presented aggressive behavior and developed metastasis to the brain and died of the disease. In this series, both cases were low-grade. Histologic grading of mucoepidermoid carcinoma carries prognostic significance ${ }^{(5)}$. Patients with high-grade mucoepidermoid carcinoma course with an aggressive clinical evolution ${ }^{(5)}$.

In this series, the carcinoma ex pleomorphic adenoma (malignant mixed tumor) was composed of benign (pleomorphic adenoma) and malignant (adenoid cystic carcinoma) components. Malignant transformation in pleomorphic adenomas has been reported ${ }^{(1)}$.

The malignancy can develop in a longstanding benign mixed tumor that has suddenly enlarged or in a recurrent tumor that may have been previously excised several times ${ }^{(1)}$.

\section{CONCLUSION}

In summary, epithelial neoplasms of the lacrimal gland were generally pleomorphic adenoma or adenoid cystic carcinoma, and malignant tumors were more frequent than benign tumors. Pleomorphic adenoma presented a good prognosis; however, adenoid cystic carcinoma with solid pattern and mucoepidermoid carcinoma showed a poor prognosis. The histopathological diagnosis and the initial staging of disease can play a significant role in patient's survival. 


\section{RESUMO}

Objetivo: Descrever e analisar as características de uma série de casos de portadores de neoplasias epiteliais primárias da glândula lacrimal, o tratamento cirúrgico, assim como os achados histopatológicos. Métodos: Avaliação retrospectiva dos arquivos de pacientes com neoplasias epiteliais primárias da glândula lacrimal, no período de 1997 até 2007. Todos os pacientes com tumores epiteliais primários da glândula lacrimal foram incluídos neste estudo. Foram analisados os dados sobre sexo, idade, características clínicas, tratamento cirúrgico, achados histopatológicos e seguimento dos pacientes. As lâminas com secções histológicas dos tumores foram revisadas pelo mesmo patologista. Resultados: No período do estudo, foram encontrados 12 pacientes, sendo $5(41,7 \%)$ portadores de tumores benignos, todos adenomas pleomórficos (tumor benigno misto), e 7 (58,3\%) com neoplasias malignas, assim distribuídos: quatro casos de carcinoma adenóide cístico, dois de carcinoma mucoepidermóide e um de carcinoma ex-adenoma pleomórfico. Analisando-se de modo global, a idade média dos portadores foi de 54,1 anos (variando de 14 a 70 anos); com média de idade de 52,4 anos (variando de 14 a 65 anos) para neoplasias benignas, e 55,3 para neoplasias malignas (variando de 26 a 70 anos). Informações do seguimento, variando de 2 a 10 anos, estavam disponíveis para todos os pacientes. Três pacientes desenvolveram metástases distantes e morreram devido à doença. Conclusões: A maioria das neoplasias epiteliais primárias da glândula lacrimal foi o adenoma pleomórfico e o carcinoma adenóide cístico no período de estudo. Os tumores malignos foram mais frequentes que os benignos. O diagnóstico histopatológico e o estadiamento inicial da doença podem desempenhar uma papel significante na sobrevida do paciente.

Descritores: Aparelho lacrimal; Neoplasias orbitárias; Adenoma; Neoplasias oculares; Doenças do aparelho lacrimal/ cirurgia; Carcinoma adenóide cístico; Carcinoma mucoepidermóide; Seguimentos

\section{REFERENCES}

1. Bernardini FP, Devoto MH, Croxatto JO. Epithelial tumors of the lacrimal gland: an update. Curr Opin Ophthalmol. 2008;19(5):409-13. Review.

2. Goder GJ. Tumours of the lacrimal gland. Orbit. 1982;1(2):91-6.

3. Shields JA, Shields CL, Scartozzi R. Survey of 1264 patients with orbital tumors and simulating lesions: The 2002 Montgomery Lecture, part 1. Ophthalmology. 2004;111(5):997-1008.
4. Font RL, Smith SL, Bryan RG. Malignant epithelial tumors of the lacrimal gland: a clinicopathologic study of 21 cases. Arch Ophthalmol. 1998;116(5): 613-6.

5. Eviatar JA, Hornblass A. Mucoepidermoid carcinoma of the lacrimal gland: 25 cases and review and update of the literature. Ophthal Plast Reconstr Surg. 1993;9(3):170-81.

6. Ferry AP, Font RL. Carcinoma metastatic to the orbit. Mod Probl Ophthalmol. 1975; $14: 377-81$

7. Paulino AF, Huvos AG. Epithelial tumors of the lacrimal glands: a clinicopathologic study. Ann Diagn Pathol. 1999;3(4):199-204.

8. Perzin Kid, Jakobiec FA, Livolsi VA, Desjardins L. Lacrimal gland malignant mixed tumor (carcinomas arising in benign mixed tumors): a clinic-pathologic study. Cancer. 1980;45(10):2593-606.

9. Font RL, Gamel JW. Epithelial tumors of the lacrimal gland: an analysis of 265 cases. In Jakobiec FS, editor. Ocular and adnexal tumors. Birmingham: Aesculapius; 1978. p.767-805.

10. Shields CL, Shields JA, Eagle RC, Rathmell JP. Clinicopathologic review of 142 cases of lacrimal gland lesions. Ophthalmology. 1989;96(4):431-5.

11. Ni C, Cheng SC, Dryja TP, Cheng TY. Lacrimal gland tumors: a clinicopathological analysis of 160 cases. Int Ophthalmol Clin. 1982;22(1):99-120.

12. Ni C, Kuo PK, Dryja TP. Histopathological classification of 272 primary epithelial tumors of the lacrimal gland. Chin Med J. 1992;105(6):481-5.

13. Ostrowski ML, Font FL, Halpern J, Nicolitz E, Barnes R. Clear cell epithelialmyoepithelial carcinoma arising in pleomorphic adenoma of the lacrimal gland. Ophthalmology. 1994;101(5):925-30.

14. Wright JE, Rose GE, Garner A. Primary malignant neoplasms of the lacrimal gland. Br J Ophthalmol.1992;76(7):401-7.

15. Rose GE, Wright JE. Pleomorphic adenoma of the lacrimal gland. $\mathrm{Br} \mathrm{J}$ Ophthalmol. 1992;76(7):395-400. Comment in: Br J Ophthalmol. 1993;77(7): 464-5. Br J Ophthalmol. 1992;76(7):386.

16. Perez DE, Pires FR, Almeida OP, Kowalski LP. Epithelial lacrimal gland tumors: a clinicopathological study of 18 cases. Otolaryngol Head Neck Surg. 2006;134(2):321-5.

17. Vangveeravong S, Katz SE, Rootman J, White V. Tumors arising in the palpebral lobe of the lacrimal gland. Ophthalmology. 1996;103(10):1606-12.

18. Obata H, Yamamoto S, Horiuchi H, Machinami R. Histopathologic study of human lacrimal gland. Statistical analysis with special reference to aging. Ophthalmology. 1995;102(4):678-86.

19. Faktorovich EG, Crawford JB, Char DH, Kong C. Benign mixed tumor (pleomorphic adenoma) of the lacrimal gland in a 6-year-old boy. Am J Ophthalmol. 1996;122(3):446-7.

20. Cates CA, Manners RM, Rose GE. Pleomorphic adenoma of the lacrimal gland in a 10-year-old girl. Br J Ophthalmol. 2002;86(2):249-50.

21. Chen CL, Chen CH, Tai MC, Lu DW, Cheng MF, Li WH. Pleomorphic adenoma of the lacrimal gland in a nine-year-old child. Clin Experiment Ophthalmol. 2005;33(6):639-41.

22. Auran J, Jakobiec F, Krebs W. Benign mixed tumor of the palpebral lobe of the lacrimal gland. Clinical diagnosis and appropriate surgical management. Ophthalmology. 1988;95(1):90-9.

23. Parks SL, Glover AT. Benign mixed tumors arising in the palpebraI lobe of the lacrimal gland. Ophthalmology. 1990;97(4):526-30.

24. Ahmad SM, Esmaeli B, Williams M, Nguyen J, Fay A, Woog J, et al. American Joint Committee on Cancer classification predicts outcome of patients with lacrimal gland adenoid cystic carcinoma. Ophthalmology. 2009;116(6): 1210-5.

25. Gamel JW, Font RL. Adenoid cystic carcinoma of the lacrimal gland: the clinical significance of a basaloid histologic pattern. Hum Pathol. 1982;13(3): 219-25

26. Esmaeli B, Ahmadi MA, Youssef A, Diba R, Amato M, Myers JN, et al. Outcomes in patients with adenoid cystic carcinoma of the lacrimal gland. Ophthal Plast Reconstr Surg. 2004;20(1):22-6. 